\title{
研究課題別中間評価結果
}

1. 研究課題名： 波長分割多重プログラマブル大規模量子シミュレータ

2. 研究代表者： 神成 文彦 （慶應義塾大学理工学部 教授）

\section{3. 中間評価結果}

本課題は、フェムト秒レーザーパルスの広帯域なスペクトル特性を、並列に利用できる周波数モー ド量子リソースと捉え、単一光パルス内に並列生成できるスクイーズドモード間の量子干涉をプログ ラムし、それらの量子相関を多段和周波発生によって時系列的に実現することで、今までにない新し い量子シミュレータの構築を行うことを目標としている。

これまでに単一レーザーパルス内の複数の周波数モード間における量子干渉を実証する周波数域 Hong-Ou-Mande 1 干渉をはじめて実験的に実証し、また本量子シミュレータ実現の上で技術的に最も難 しいと目されていた多段和周波発生による量子相関計測を圧縮センシングの導入により大幅に簡略化 できることを見出した。企業との非線形素子の共同開発等，個々の要素技術開発と合わせて概ね計画 通りに進捗している。さらに、高繰り返し $\mathrm{GHz}$ 周波数コムの縦モードを波長多重高次元量子ビットと 捉える新規なアイデアも生み出しており、量子シミュレータに限らず、単一レーザーパルスの周波数 モードを利用した独創的な量子情報処理の研究が進捗できている。今後は，周波数域量子シミュレー 夕の原理実証実験の先にある周波数モード間量子相関のより深い理解と応用を進めていくとともに、 国際共同研究もいっそう推進していただきたい。 